\title{
Post-fledging and winter migration of Adélie penguins Pygoscelis adeliae in the Mawson region of East Antarctica
}

\author{
Judy Clarke ${ }^{1, *}$, Knowles Kerry $^{1}$, Charles Fowler ${ }^{2}$, Ruth Lawless ${ }^{1}$, Stefan Eberhard ${ }^{1,3}$, \\ Ray Murphy ${ }^{1,4}$
}

\author{
${ }^{1}$ Australian Antarctic Division, Channel Hwy, Kingston, Tasmania 7050, Australia \\ ${ }^{2}$ Colorado Center for Astrodynamics Research, University of Colorado, Boulder, Colorado 803309-0431, USA
}

${ }^{3}$ Present address: Caveworks, Caves Road, Forest Grove, Western Australia 6286, Australia

${ }^{4}$ Present address: Sea Fisheries, DPIWE, 1 Franklin Wharf, Hobart, Tasmania 7000, Australia

\begin{abstract}
Seven fledging Adélie penguin Pygoscelis adeliae chicks and 4 post-moult adults were satellite tracked using the Argos system during the winters of 1995-97 and 1998, respectively. Six fledglings departed from Béchervaise Island near Mawson station $\left(67^{\circ} 35^{\prime} \mathrm{S}, 62^{\circ} 49^{\prime} \mathrm{E}\right)$ during late February of 1996 and 1997 and were tracked for up to 5 mo before transmissions stopped. The 7th fledgling left Magnetic Island near Davis station (68 $\left.33^{\prime} \mathrm{S}, 77^{\circ} 54^{\prime} \mathrm{E}\right)$ in February 1995 and was tracked for $32 \mathrm{~d}$. All fledglings travelled northward initially, then westward along the edge of the fast ice or in the pack-ice. Fledglings had travelled between 536 and $1931 \mathrm{~km}$ to the west of their natal colonies by the time transmissions ceased. Adult Adélie penguins were tracked between March and October 1998, following completion of their annual moult at Bechérvaise Island. Instruments were set to transmit for $2 \mathrm{~h}$ every 10th day over the first $5 \mathrm{mo}$ and $1 \mathrm{~d}$ in 4 thereafter. Adult birds travelled westward until July, after which time they moved north within the expanding pack-ice into known areas of high krill concentration before returning eastward toward their breeding sites. Penguin movements over the winter months were closely related to those of sea ice in the region. Ice motion patterns were in turn influenced by gyral oceanic current systems and wind. We propose that large gyral oceanic systems provide a means for Adélie penguins to reduce costs of transport as they travel into regions of high productivity during winter and return to their breeding colonies in spring.
\end{abstract}

KEY WORDS: Adélie penguin · Winter migration · Satellite tracking $\cdot$ Fledglings $\cdot$ Sea-ice motion · Antarctic divergence $\cdot$ East Antarctica $\cdot$ Oceanic gyres

\section{INTRODUCTION}

Adélie penguins Pygoscelis adeliae are one of the most numerous avian species breeding along the coast of East Antarctica, with an estimated 197000 pairs nesting annually in the Vestfold Hills of Prydz Bay, and approximately 83000 pairs breeding in the Mawson region of Mac.Robertson Land (Woehler 1993). Although the biology of these birds has been well studied during their summer breeding season (e.g. Whitehead 1989, Whitehead et al. 1990, Kerry et al. 1995, Wata- nuki et al. 1997, Clarke et al. 1998, Clarke 2001), little is known about the distribution or behaviour of Adélie penguins over the winter months. Adélie penguins are known to spend their winters among the pack-ice (Ainley et al. 1992, 1993, 1994, 1998, Fraser \& Trivelpiece 1996) but how far they migrate as juveniles or adults, and whether they travel continuously or remain in specific regions, is poorly understood.

There are 3 records published to date describing the use of satellite technology to investigate post-breeding migration of Adélie penguins subsequent to their 
annual moult. Kerry et al. (1995) described the satellite tracking of 3 adult Adélie penguins departing the Béchervaise Island colony near Mawson in March 1993. These birds provided data from March until early June that year, and were tracked westward along the continental shelf break at the approximate position of the flaw lead where the pack-ice breaks away from the fast ice. Davis et al. (1996) tracked 2 adult Adélie penguins departing the Cape Bird colony in the Ross Sea in February 1991 for the first 5 mo of their winter migration, and in 1998 a single Adélie penguin was tracked from Cape Hallett over a similar period (Davis et al. 2001). These 3 birds travelled north and west toward what was assumed to be a common wintering ground to the north-west of the Balleny Islands. Similar technology was used by Wilson et al. (1998) to determine the winter migration of a single chinstrap penguin Pygoscelis antarctica; this species is known to inhabit more northern ice-free waters outside of its summer breeding season (Ainley et al. 1992, 1994).

Advances in satellite-based global imaging techniques (Emery et al. 1997) combined with hydrographic data (Orsi et al. 1995), iceberg movement patterns (Tchernia \& Jeannin 1984), and information from satellite-tracked drifting buoys (Allison 1989, Heil \& Allison 1999) have allowed the identification of oceanic gyres and water-mass boundaries within the Indian Ocean sector and around the continent as a whole. A narrow coastal current, known as the East Wind Drift, flows westward around the continental margin; to the north of this lies the broad eastward flowing Antarctic Circumpolar Current (ACC). Regions of northward flow interrupt the coastal current thereby transporting cold southern waters into the $\mathrm{ACC}_{i}$ these are presumed to delimit the western edges of great cyclonic gyres (Tchernia \& Jeannin 1984, Emery et al. 1997). pack-ice covers up to $19 \times 10^{6} \mathrm{~km}^{2}$ of the Southern Ocean in winter (Cavalieri et al. 1997) and extends well into the water mass of the ACC. Patterns of ice motion are determined by wind and ocean currents; thus movements of Adélie penguins wintering in the pack-ice can be expected to be influenced by these factors also.

The post-moult Adélie penguins tracked from Béchervaise Island in 1993 travelled westward at approximately the same speeds as the ocean currents in that region (Allison 1989, Kerry et al. 1995). Lack of data beyond the end of May precluded discovery of how far around the continent the penguins migrated during the winter months or at what latitude they travelled back to the colony in spring. This paper describes the use of satellite telemetry to determine the migratory patterns of both post-moult adult and fledgling Adélie penguins during the autumn and winter months of 1995 to 1998 in relation to ocean currents and ice drift. It is the second investigation of post-breeding adult migration in this region and the first to cover the majority of the winter period. It is also the first tracking study to be reported for fledgling Adélie penguins at any locality.

\section{MATERIALS AND METHODS}

The study took place between late February and October during the winters of 1995 to 1998 . The majority of the work was carried out at the Adélie penguin colony on Béchervaise Island $\left(67^{\circ} 35^{\prime} \mathrm{S}, 62^{\circ} 49^{\prime} \mathrm{E}\right)$ near Mawson Station in Mac.Robertson Land, East Antarctica. Ten of the 11 tracked birds were instrumented at this colony; the remaining bird, a fledgling, originated at a colony on Magnetic Island $\left(68^{\circ} 33^{\prime} \mathrm{S}, 77^{\circ} 54^{\prime} \mathrm{E}\right)$ near Davis station in Prydz Bay. Béchervaise Island lies approximately $100 \mathrm{~km}$ south from the edge of the continental shelf break, whereas Magnetic Island is located $180 \mathrm{~km}$ south of the shelf edge within the relatively shallow Prydz Bay. Sea-ice extends northward to approximately $59^{\circ} \mathrm{S}$ during winter; in summer it breaks out to the coast at both sites.

Satellite-tracked radio transmitters (known as platform transmitter terminals or PTTs) were attached to 7 fledgling chicks at the end of the breeding season. One fledgling was instrumented at Magnetic Island in late February 1995, 2 at Béchervaise Island on 25 February 1996, and the remaining 4 at Béchervaise Island on 21 February 1997. PTTs were deployed on 4 post-moult adults of unknown breeding status on 3 March 1998 at Béchervaise Island. All birds were implanted with electronic identification transponders (Clarke \& Kerry 1998) to enable their detection if they later returned to the colony to breed.

The PTTs used were ST-10 models produced by Telonics. They were tapered at the front and packaged in resin by Sirtrack to withstand diving to $200 \mathrm{~m}$. Each weighed $90 \mathrm{~g}$ after packaging. The instruments were attached using fast-setting cyanoacrylic glue (Loctite ${ }^{\mathrm{TM}}$ 401) and cable ties to the centre of the lower back (Fig. 1). All PTTs were factory-set to transmit in dutycycles of $24 / 72 \mathrm{~h}$ on/off. PTTs carried by fledglings commenced these transmission cycles immediately following deployment and provided data for up to 4 mo. In contrast, those attached to post-moult adults were programmed to transmit infrequently over the first $5 \mathrm{mo}(2 \mathrm{~h}$ every $10 \mathrm{~d})$, before commencing their normal duty-cycles in July. Thus battery power was conserved during autumn, and adult birds could be tracked through winter and into spring.

Transmissions were detected by National Oceanic and Atmospheric Administration (NOAA) satellites and positions calculated through the Argos location 
system (Argos CLS). Satellite data were analysed and mapped using custom programs written at the Australian Antarctic Division. Average travel speeds were calculated from distances travelled between successive duty-cycle periods (4 d). Quality of PTT locations was classed from 0 to 3 on the basis of several performance characteristics, including stability of transmission frequencies, movement of the PTT during transmissions, and satellite elevation (Service Argos 1996). Class 1, 2 and 3 fixes provide 1 SD accuracies of 1000, 350 and $150 \mathrm{~m}$ respectively, and the accuracy of Class 0 locations cannot be specified (Service Argos 1996). We collected location information from all fixes of Class 0 to 3, but only those of Class 1 to 3 were used to plot tracks and calculate travelling speeds and distances covered.

Image processing of Special Sensor Microwave/ Imager (SSM/I) data was used to determine patterns of ice motion throughout the region traversed by the Adélie penguins in winter. Ice concentrations were generated using the 'bootstrap' algorithm and obtained from the National Snow and Ice Data Center (NSIDC) (Comiso 1995). A full description of the data set can be found at www.nsidc.colorado.edu/data/ docs/daac/nsidc0079_bootstrap_seaice.gd.html\#9.1.1

Ice velocity maps were derived by determining ice displacement from sequential imagery using a maximum cross-correlation (MCC) method (Emery et al. 1997). A spatial coherence filter was applied to filter out incorrect vectors caused by weather effects and distortions in the ice fields in areas of large velocity gradients. Vectors were obtained from both the 37 and $85 \mathrm{GHz}$ channels. Optimal interpolation techniques were then used to generate daily ice motion maps. The same series of operations were performed on

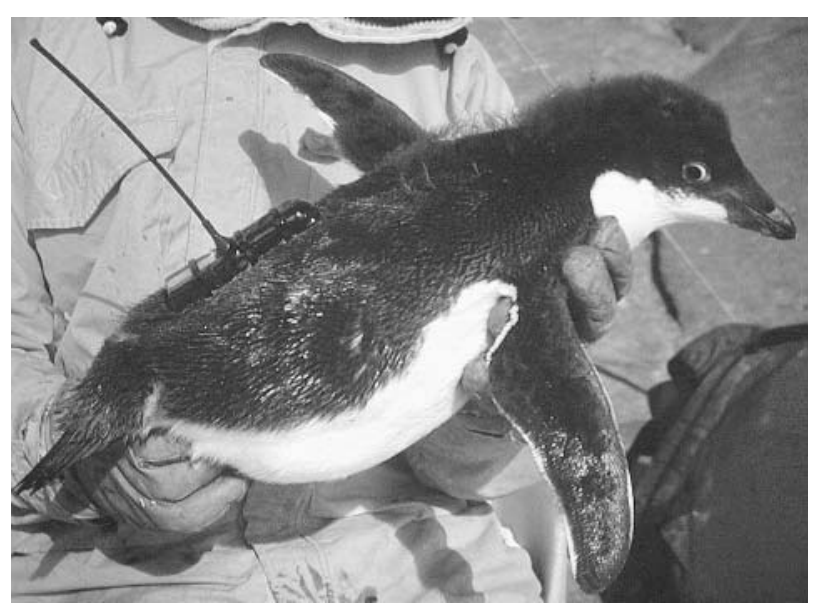

Fig. 1. Pygoscelis adeliae fledgling with a platform transmitter terminal (PTT) attached to feathers using cyanoacrylic glue and cable ties
Advanced Very High-Resolution Radiometer (AVHRR) imagery and combined with the passive microwave vectors. However, because of the extreme cloudy conditions, the vectors from the passive microwave had the most influence on the final vector fields.

Average daily speeds of penguin movement were calculated by linear interpolation between fixes. Fiveday running means of the $u$ (north-south) and $v$ (eastwest) components of both the penguin and ice velocities (in reference to a polar grid) were used for comparisons of penguin movement with ice motion.

Changes in sea-ice extent and locations of the fastice edge were determined from AVHRR images received at Casey station $\left(66^{\circ} 28^{\prime} \mathrm{S}, 110^{\circ} 53^{\prime} \mathrm{E}\right)$. Sea-ice began to reform in March each year, and by mid-April fast ice around Enderby Land typically extended to the north of $67^{\circ} \mathrm{S}$. Areas of open water persisted throughout much of the winter, occurring particularly in the region of the continental shelf break and as leads in the pack-ice (see also Kerry et al. 1995).

\section{RESULTS}

\section{Fledglings}

The Adélie penguin fledgling that departed Magnetic Island, Davis in 1995 was tracked for $32 \mathrm{~d}$ before transmissions stopped (Table 1, Fig. 2). The 2 fledglings that left Béchervaise Island, Mawson in 1996 were tracked for 50 and $90 \mathrm{~d}$. The 4 fledglings instrumented in 1997 gave fixes for periods ranging between 82 and $142 \mathrm{~d}$ (Table 1, Fig. 2).

The fledglings that departed Béchervaise Island in 1996 initially travelled northward to $63^{\circ} 16^{\prime} \mathrm{S}$ (250 km north of the shelf break) before returning closer to the continent and moving westward (Fig. 2). These birds travelled overall distances of 1160 and $2735 \mathrm{~km}$ from their natal colonies before transmissions stopped (Table 1). The fledgling tracked from Davis the previous year moved $1075 \mathrm{~km}$ westward (Table 1, Fig. 2) before transmissions ceased. In 1997, 3 of the 4 fledglings initially chose to travel north and, in 2 cases, up to $200 \mathrm{~km}$ east before turning westward for the remainder of their journeys (Fig. 2). The final bird travelled westward for the entirety of its trip (Fig. 2). These fledglings reached straight-line distances of up to 1931 $\mathrm{km}$ from Béchervaise Island by the time communications ceased, and travelled between 2324 and $3991 \mathrm{~km}$ in total (Table 1).

All fledglings were moving westward by the end of March in every year, but at varying latitudes (Fig. 2). During April the majority acted similarly to the adults described in Kerry et al. (1995) and travelled along the shelf break at the level of the fast-ice pack-ice junction 


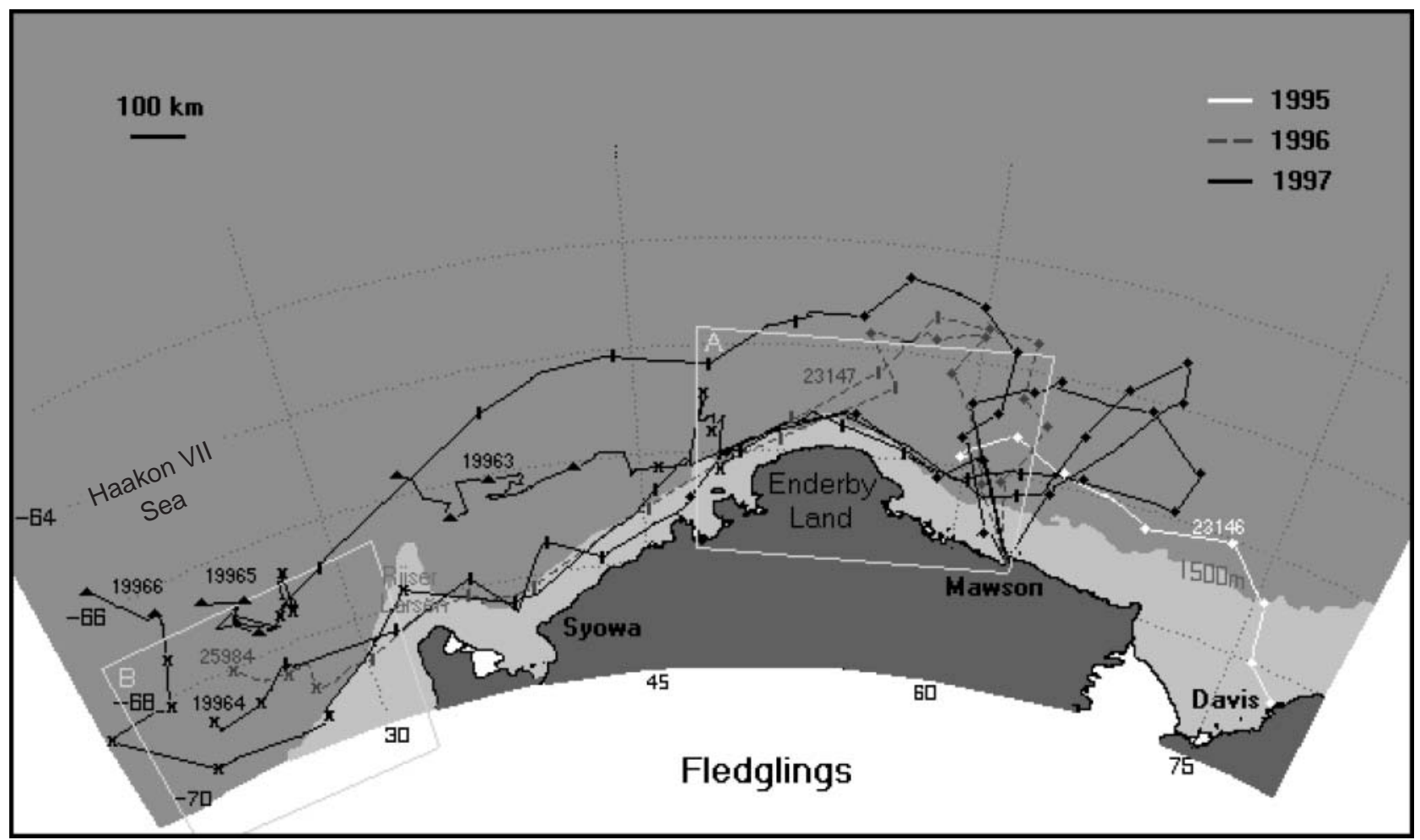

Fig. 2. Pygoscelis adeliae. Part of the East Antarctic coastline showing the journeys of 7 fledglings tracked during the 1995 to 1997 winters. Symbols designate calendar months during which each journey took place: Feb-Mar; I April; $\times$ May; $\Delta$ June-July. The position of the $1500 \mathrm{~m}$ isobath indicates the continental shelf break. Boxes A and B specify the regions encompassed by the satellite images of ice extent in Fig. 3

(Figs. 2 \& 3A). One individual, however, travelled westward north of the ice before gradually moving southward into the developing pack-ice. Fig. 3 shows typical sea-ice conditions during April and July. Although images were unavailable for the years in question, pat- terns of sea-ice growth and decay between autumn and spring show little inter-annual variation. Thus the images shown for 1999 and 2000 can be considered typical of the region. Penguins moving westward around Enderby Land in March and April appeared to

Table 1. Pygoscelis adeliae. Time periods and distances over which penguins were tracked. Colony of origin at Davis was Magnetic Island and at Mawson was Béchervaise Island. Birds were resighted alive at the location of origin in one or more subsequent breeding seasons. No searches were carried out at Davis. Total distance tracked was calculated as the sum of distances between successive fixes of quality 1 to 3 (see 'Materials and methods'). Maximum distance from colony was measured as straight-line distance between colony of origin and farthest point reached. PTT: Platform transmitter terminal

\begin{tabular}{|c|c|c|c|c|c|c|c|}
\hline PTT & Year & Origin & Resighted & Dates tracked & $\begin{array}{l}\text { Days } \\
\text { tracked }\end{array}$ & $\begin{array}{l}\text { Total distance } \\
\text { tracked }(\mathrm{km})\end{array}$ & $\begin{array}{l}\text { Max. distance } \\
\text { from colony }(\mathrm{km})\end{array}$ \\
\hline \multicolumn{8}{|c|}{ Fledglings } \\
\hline 23146 & 1995 & Davis & & 23 Feb-27 Mar & 32 & 1075 & 835 \\
\hline 23147 & 1996 & Mawson & No & 25 Feb-14 Apr & 50 & 1160 & 536 \\
\hline 25984 & 1996 & Mawson & Yes & 25 Feb-24 May & 90 & 2735 & 1634 \\
\hline 19963 & 1997 & Mawson & No & $20 \mathrm{Feb}-12 \mathrm{Jul}$ & 142 & 3732 & 1276 \\
\hline 19964 & 1997 & Mawson & yes & 20 Feb-13 May & 82 & 2324 & 1690 \\
\hline 19965 & 1997 & Mawson & No & 20 Feb-7 Jul & 137 & 3484 & 1689 \\
\hline 19966 & 1997 & Mawson & No & 20 Feb-6 Jun & 106 & 3991 & 1931 \\
\hline \multicolumn{8}{|c|}{ Post-moult adults } \\
\hline 2670 & 1998 & Mawson & Yes & 9 Mar-11 Sep & 186 & 2747 & 1403 \\
\hline 2671 & 1998 & Mawson & No & 9 Mar-30 Mar & 21 & 209 & 200 \\
\hline 2672 & 1998 & Mawson & No & 9 Mar-25 Oct & 230 & 1109 & 1050 \\
\hline 2673 & 1998 & Mawson & Yes & 9 Mar-27 Sep & 202 & 2396 & 1653 \\
\hline
\end{tabular}




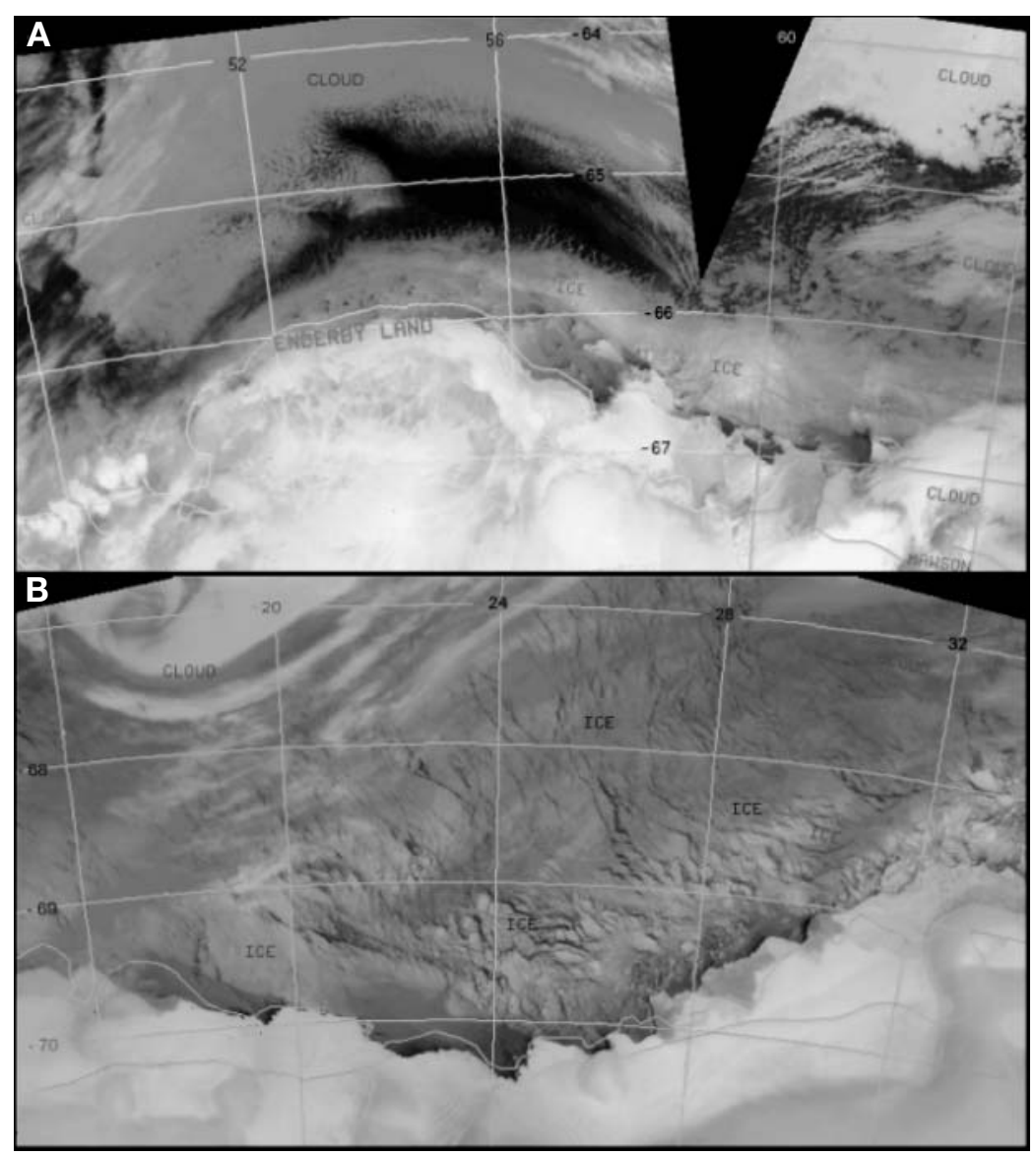

Fig. 3. Satellite images of parts of the study area showing (A) advancing sea-ice extent around Enderby Land on 11 April 2000 and (B) heavy pack-ice in the Haakon VII Sea on 10 July 1999 travel at the outer edge of the developing ice. The 5 fledglings that were tracked west of $45^{\circ} \mathrm{E}$ gradually moved farther offshore within extensive packice as winter progressed (Figs. 2 \& 3B).

Fledglings travelled at average speeds (between duty-cycles) of 2 to $68 \mathrm{~km} \mathrm{~d}^{-1}$, and covered between 380 and $1402 \mathrm{~km}$ per complete month of tracking (Table 2). The furthest point reached from the colony was $1931 \mathrm{~km}$ west (Table 1, Fig. 2), but the birds may have continued to travel farther westward after their PTTs ceased transmitting. During March and April fledglings travelled westward at mean monthly speeds ranging between 26 and $43 \mathrm{~km}$ $\mathrm{d}^{-1}$ (Table 2, Fig. 2). These speeds were greater than those of previously tracked post-moult adults of 11 to $34 \mathrm{~km}$ $\mathrm{d}^{-1}$ (Kerry et al. 1995); the majority were also faster than the ocean currents in that region which average 20 to $30 \mathrm{~km}$ $\mathrm{d}^{-1}$ overall, with a maximum mean velocity of $42 \mathrm{~km} \mathrm{~d}^{-1}$ around Cape Anne $\left(52^{\circ} \mathrm{E}\right)$ (Allison 1989, Heil \& Allison 1999). After the end of April the fledglings slowed down (Table 2, Fig. 2) and the majority moved at mean monthly speeds more similar to those expected of pack-ice movement in the region (15 to $25 \mathrm{~km} \mathrm{~d}^{-1}$ ) (Heil \& Allison 1999).

Table 2. Pygoscelis adeliae. Monthly travel distances and average travel speeds $( \pm \mathrm{SD})$ for penguins carrying platform transmitter terminals (PTTs) during winter. Travel speeds between successive transmission periods were averaged for each month. The number of transmission cycles per month is shown after each entry

\begin{tabular}{|c|c|c|c|c|c|c|c|c|c|c|c|c|}
\hline \multirow[t]{2}{*}{ PTT } & \multicolumn{5}{|c|}{ _Distance $(\mathrm{km})$} & \multicolumn{7}{|c|}{ - Mean speed $\left(\mathrm{km} \mathrm{d}^{-1}\right)$} \\
\hline & Mar & Apr & May & Jun & Jul & Mar & Apr & & May & Jun & Jul & \\
\hline \multicolumn{13}{|c|}{ Fledglings } \\
\hline 23146 & 964 & & & & & $34( \pm 9.0) 7$ & 7 & & & & & \\
\hline 23147 & 554 & 584 & & & & $23( \pm 10.7) 6$ & $630( \pm 8.1)$ & 3 & & & & \\
\hline 25984 & 805 & 1355 & 397 & & & $29( \pm 6.8) 7$ & $743( \pm 18.0)$ & 8 & $16( \pm 6.0) \quad 6$ & & & \\
\hline 19963 & 1221 & 834 & 695 & 663 & 196 & $38( \pm 15.5) 8$ & $8 \quad 26( \pm 12.6)$ & 8 & $25( \pm 11.5) 7$ & $20( \pm 12.5) 8$ & $16( \pm 2.7)$ & 3 \\
\hline 19964 & 946 & 1119 & 188 & & & $30( \pm 12.6) 8$ & $835( \pm 13.2)$ & 8 & $15( \pm 9.0) 3$ & & & \\
\hline 19965 & 1013 & 1359 & 380 & 511 & 146 & $32( \pm 8.3) \quad 8$ & $8 \quad 43( \pm 12.4)$ & 6 & $13( \pm 5.2) 7$ & $16( \pm 7.1) 8$ & $17( \pm 10.2)$ & 2 \\
\hline \multirow[t]{2}{*}{19966} & 1189 & 1402 & 1182 & 212 & & $38( \pm 6.8) \quad 8$ & $843( \pm 18.0)$ & 8 & $42( \pm 12.2) 7$ & $24( \pm 21.1) 2$ & & \\
\hline & Mar-Jun & Jul & Aug & Sep & Oct & Mar-Jun & Jul & & Aug & Sep & Oct & \\
\hline \multicolumn{13}{|l|}{ Adults } \\
\hline 2670 & 1525 & 102 & 606 & 515 & & $12( \pm 4.4) \quad 5$ & $5 \quad 10( \pm 0.0)$ & 1 & $23( \pm 12.6) 6$ & $41( \pm 15.6) 3$ & & \\
\hline 2671 & 209 & & & & & $10( \pm 12.2) 2$ & $10(-0,0)$ & & & & & \\
\hline 2672 & $1047^{\mathrm{a}}$ & & & & 63 & $4( \pm 0.0)^{\mathrm{a}} 1$ & 1 & & & & $8( \pm 0.0)$ & 1 \\
\hline 2673 & 1617 & 166 & 293 & 321 & & $15( \pm 0.9)$ & $8( \pm 3.9)$ & 2 & $10( \pm 5.3) 6$ & $11( \pm 4.8) 7$ & & \\
\hline
\end{tabular}


Proportions of Class 1, 2 and 3 fixes during each month of travel were calculated for the fledglings tracked in 1997 (Table 3). For all 4 fledglings pooled there was a significant linear relationship between the proportion of Class 1 fixes and mean distance travelled per day (linear regression analysis; adj $r^{2}=0.320$, $\mathrm{p}=0.011$ ). Higher proportions of Class 1 fixes can be expected from swimming birds in comparison to those resting on the ice because PTTs must be at the surface for a certain length of time before accurate locations can be determined (Service Argos 1996, Clarke \& Kerry unpubl. data). Lower mean speeds and greater proportions of Class 2 and 3 fixes obtained from the fledglings from May onward (Table 3) suggest that the birds were spending more of their time resting on ice floes and less time travelling in the water than during the previous 2 mo.

\section{Post-moult adults}

Movements of 3 of the post-moult adults instrumented in 1998 are shown in Fig. 4, along with the tracks of those studied in 1993 (Kerry et al. 1995) for comparison. Intermittent transmissions were received from PTTs 2670 and 2673 between March and June prior to commencement of regular fixes from July to September. No signals from PTT 2672 were detected between March and September but transmissions

Table 3. Pygoscelis adeliae. Average travel distances and proportions of Class 1 to 3 fixes obtained for the 4 fledglings tracked in 1997. Class 1 fixes are the least accurate and most likely to be obtained when birds are swimming

\begin{tabular}{|lccccc|}
\hline Month & PTT & $\begin{array}{c}\text { Mean distance } \\
\text { travelled per day } \\
(\mathrm{km})\end{array}$ & $\begin{array}{c}\text { Proportion } \\
\text { Class 1 fixes }\end{array}$ & $\begin{array}{c}\text { Proportion } \\
\text { Class 2 fixes }\end{array}$ & $\begin{array}{c}\text { Proportion } \\
\text { Class 3 fixes }\end{array}$ \\
\hline March & 19963 & 38 & 0.97 & 0.03 & 0.00 \\
& 19964 & 30 & 0.83 & 0.17 & 0.00 \\
& 19965 & 32 & 0.93 & 0.04 & 0.02 \\
& 19966 & 38 & 0.90 & 0.10 & 0.00 \\
April & 19963 & 26 & 0.77 & 0.21 & 0.02 \\
& 19964 & 35 & 0.63 & 0.21 & 0.15 \\
& 19965 & 43 & 0.93 & 0.05 & 0.02 \\
& 19966 & 43 & 0.78 & 0.21 & 0.02 \\
May & 19963 & 25 & 0.75 & 0.22 & 0.04 \\
& 19964 & 15 & 0.55 & 0.36 & 0.09 \\
& 19965 & 13 & 0.78 & 0.18 & 0.03 \\
& 19966 & 42 & 0.66 & 0.16 & 0.18 \\
June & 19963 & 20 & 0.72 & 0.23 & 0.05 \\
& 19965 & 16 & 0.52 & 0.40 & 0.08 \\
& 19966 & 24 & 0.41 & 0.47 & 0.12 \\
July & 19963 & 16 & 0.14 & 0.43 & 0.43 \\
& 19965 & 17 & 0.44 & 0.44 & 0.11 \\
\hline
\end{tabular}

were recorded briefly over an $8 \mathrm{~d}$ period in late October. PTT 2671 gave intermittent low quality positions during March but failed to commence regular communications when expected in July (Table 1).

Intermittent fixes received from PTTs 2670 and 2673 between March and June showed that the penguins travelled westward at the edge of the continental slope in a similar fashion to that described for post-moult and incubating adult birds from the same colony in Kerry et al. (1995). Their westward journeys took place at average speeds of 12 and $15 \mathrm{~km} \mathrm{~d}^{-1}$ overall (Table 2), which is similar to or slightly slower than the speed of the westward current in that region (Allison 1989, Heil \& Allison 1999).

By July the penguins carrying PTTs 2670 and 2673 had travelled around Enderby Land and into the Haakon VII Sea, at which point they turned northward. During July the birds travelled more slowly, averaging speeds of 10 and $8 \mathrm{~km} \mathrm{~d}^{-1}$, respectively. The furthest points reached from the breeding colony at Mawson were 1653 and $1403 \mathrm{~km}$ (Table 1). Penguin 2670 then travelled along the slope edge of the Rïser Larsen before returning eastward at latitudes between 61 and $63^{\circ} \mathrm{S}$, averaging monthly speeds of 23 and $41 \mathrm{~km} \mathrm{~d}^{-1}$ (Table 2). These speeds were faster than those of drifting buoys observed in eastward-flowing waters north of the Antarctic Divergence, which averaged $15.1 \mathrm{~km}$ $\mathrm{d}^{-1}$ (Heil \& Allison 1999). Penguin 2673 moved gradually northward within the Haakon VII Sea, presumably foraging in the pack-ice which covers the region at that time of year (Fig. 3B). Transmissions were only received from PTT 2672 during October, so we do not know whether the penguin had been foraging farther west prior to that time.

Fig. 5 shows monthly mean ice-drift patterns over the period during which penguins were tracked: July to October 1998. Newly formed sea-ice is carried westward during the autumn months by the wind-driven westwardflowing coastal current; this movement has also been documented from satellite-tracked drifting buoys (Allison 1989, Heil \& Allison 1999). Packice is advected across the Antarctic Divergence into the eastward flowing ACC as the extent of the sea-ice increases during winter. The $u$ and $v$ components of velocity for penguins carrying PTTs 2670 and 2673 were significantly correlated with ice motion over the period July to September (Pearson product moment correlation; 


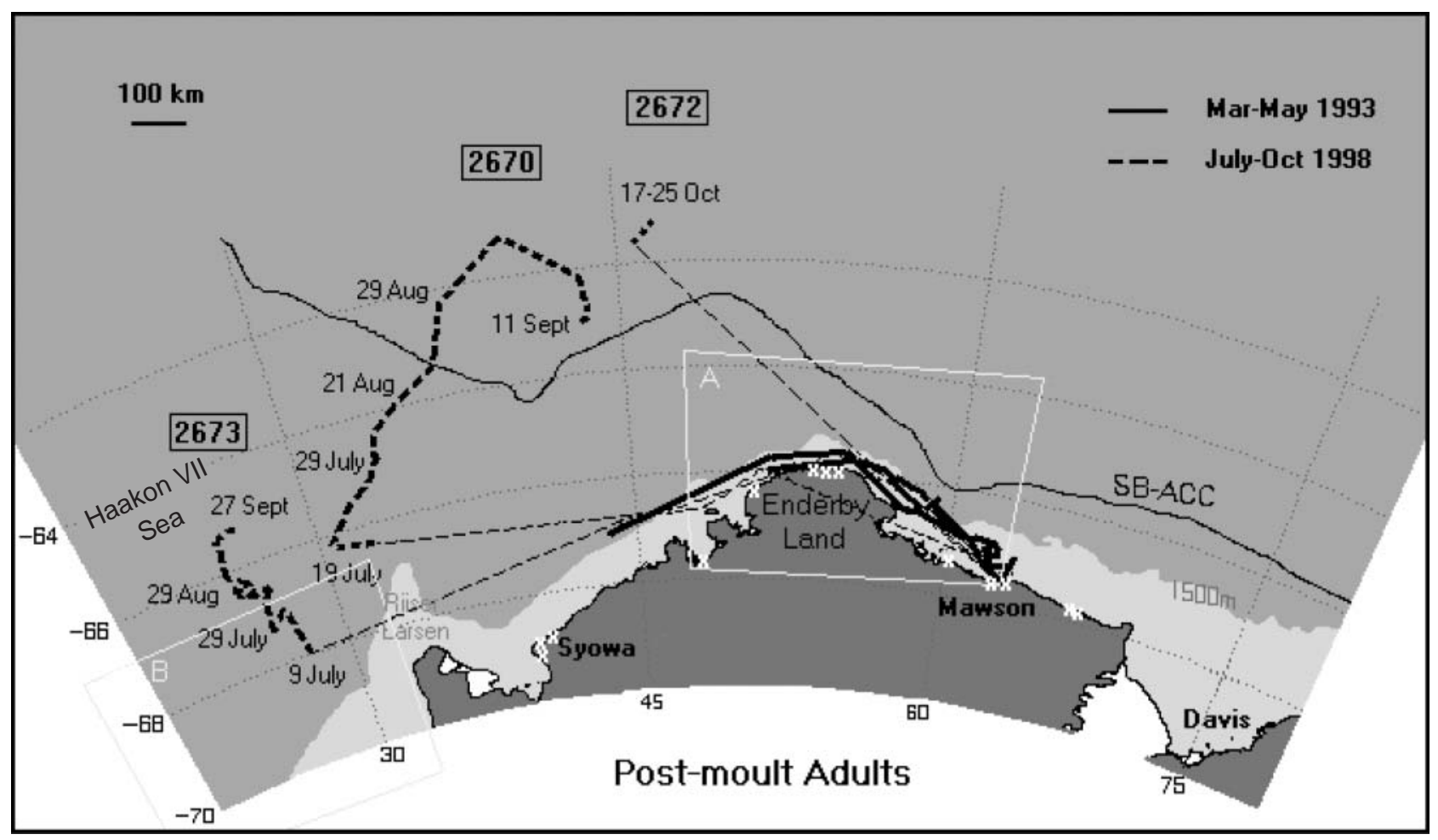

Fig. 4. Pygoscelis adeliae. The East Antarctic coastline showing the journeys of post-moult adults tracked during the 1993 and 1998 winters. 1993 tracks are adapted from Kerry et al. (1995). Platform transmitter terminal (PTT) 2671 failed to transmit after March and is thus omitted. The position of the southern boundary of the Antarctic Circumpolar Current (SB-ACC) is shown (adapted from Orsi et al. 1995). Asterisks indicate the positions of major Adélie penguin colonies along the coastline (from Woehler 1993). The position of the $1500 \mathrm{~m}$ isobath indicates the continental shelf break. Boxes A and B specify the regions encompassed by the satellite images of ice extent in Fig. 3

$u$ component: $\mathrm{r}=0.425, \mathrm{p}<0.001 ; \mathrm{r}=0.639, \mathrm{p}<0.001 ; \mathrm{V}$ component: $\mathrm{r}=0.553, \mathrm{p}<0.001 ; \mathrm{r}=0.713, \mathrm{p}<0.001$ for PTTs 2670 and 2673, respectively). After 21 August, although velocities remained correlated $(\mathrm{r}=0.774, \mathrm{p}<$ $0.001 ; \mathrm{r}=0.741, \mathrm{p}<0.001$ for $u$ and $v$ components, respectively), the penguin carrying PTT 2670 travelled significantly faster than the ice (paired $t$-test; $t=7.390$, $\mathrm{df}=20, \mathrm{p}<0.001 ; t=-2.639, \mathrm{df}=20, \mathrm{p}=0.016$ for $u$ and $v$ components, respectively). Data from this bird also showed a positive relationship between mean travel speed and proportion of Class 1 fixes received per duty cycle over this latter period (linear regression analysis; adj $\mathrm{r}^{2}=0.922, \mathrm{p}=0.002$ ).

Day:night ratios of fixes received from each penguin were compared with the day:night ratio of pass frequencies of Argos satellites covering the region in question. Both Adult 2670 and Adult 2673 showed significantly lower numbers of fixes between 06:00 and 18:00 $\mathrm{h}$ local time than would be expected if the PTTs were constantly visible to the satellites (chisquared tests: $\chi^{2}=6.366, \mathrm{df}=1, \mathrm{p}=0.012 ; \chi^{2}=6.067$, $\mathrm{df}=1, \mathrm{p}=0.014$ for PTTs 2670 and 2673, respectively).

\section{Penguin survival}

Adélie penguin breeding colonies in the Mawson region were checked for the presence of tagged birds during years subsequent to this study. Fledglings 25984 and 19964 (tracked in 1996 and 1997, respectively) returned to Béchervaise Island in January 2000 as non-breeding birds (Table 1); the latter (a male) was observed attempting to breed the following year. We detected postmoult Adult 2670 (a male) back in the Béchervaise Island breeding colony in November 1998 (minus its PTT). The last transmission from this bird's instrument had been received on 11 September 1998 when it was moving eastward back toward Mawson (Figs. 4 \& 5). Post-moult Adult 2673 (a female) was detected in a breeding colony on Welch Island, $7 \mathrm{~km}$ away from Béchervaise Island in December 2000. Transmissions from this penguin's PTT had ceased in late September 1998 when the bird was still $1612 \mathrm{~km}$ from Mawson. It is unlikely that the bird could have returned to breed that same year. However, it may have been a young non-breeder when instrumented in 1998 because its age and breeding status at capture were unknown. 


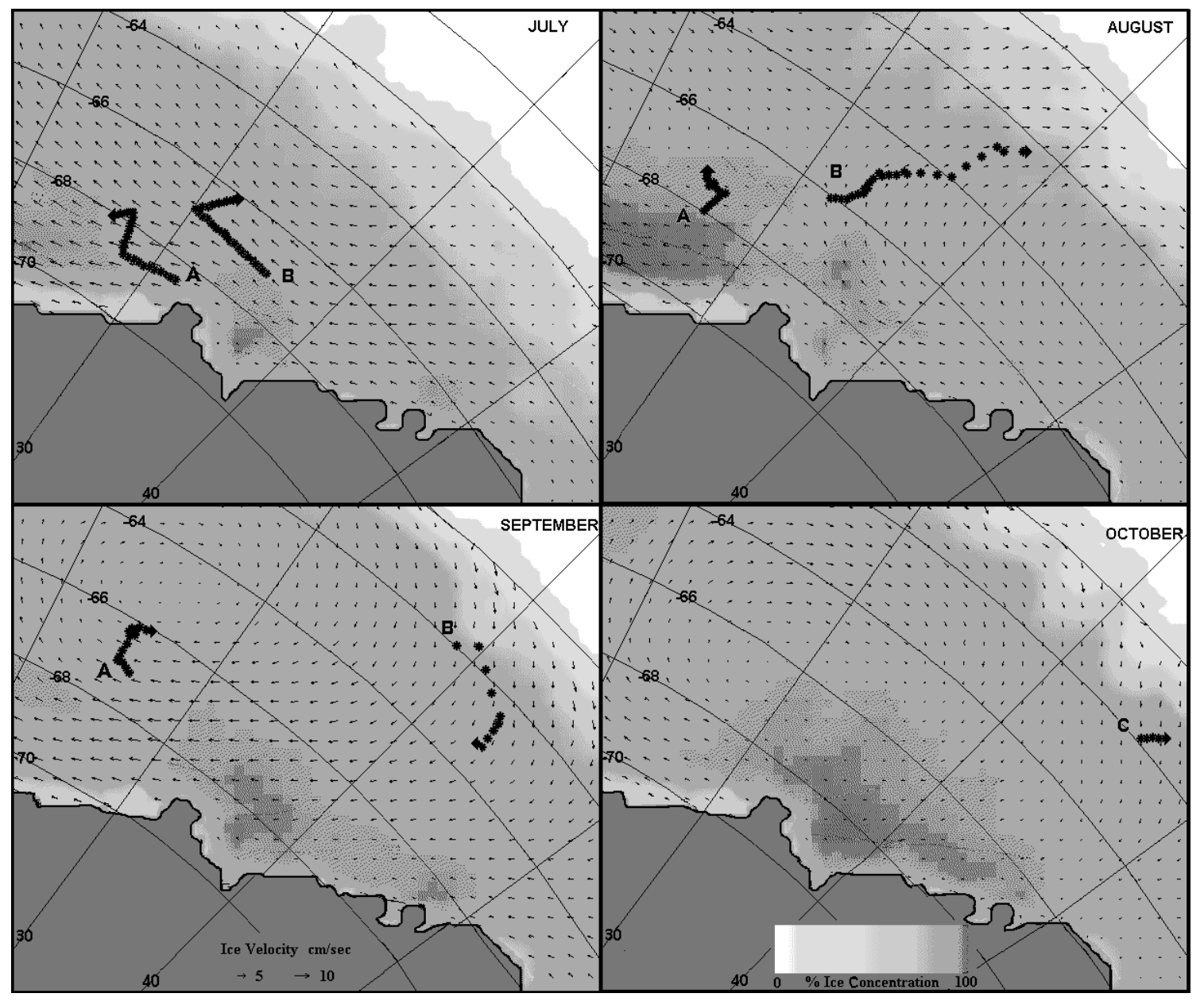

Fig. 5. Pygoscelis adeliae. Tracks of penguins carrying platform transmitter terminals (PTTs) 2673 (A), 2670 (B) and 2672 (C) during the months of July to October 1998 superimposed upon maps of average sea-ice extent, concentration and motion for the same months

\section{DISCUSSION}

\section{Reliability of data}

A difficulty common among many long-term tracking studies is ensuring that instruments remain attached throughout the period of interest. Davis et al. (2001) drew attention to this problem and suggested that transmitter loss is due to feather breakage rather than separation of the instrument from the plumage. Scientists studying migration patterns of Magellanic penguins Spheniscus magellanicus have come to the same conclusion (Stokes et al. 1998, Pütz et al. 2000). Our observations support this premise, as during studies within the breeding season we have regularly seen penguins preening around the margins of attached instruments, particularly upon exit from the water. Post-moult Adult 2670 had a patch of broken feathers at the site of PTT attachment when it returned to the colony after the 1998 winter. The PTT had had suffi- cient battery life to last up until late October; the fact that transmissions ceased earlier suggests it fell off the bird sometime soon after the last fix was received. The fact that penguins fail to return with their instruments intact after $8 \mathrm{mo}$ at sea raises the question of whether the transmissions received derive from PTTs on the backs of penguins or from instruments discarded onto the ice. We discuss below some analyses we carried out to attempt to resolve this dilemma.

Average travel speeds of the fledglings during March and April (Table 2) tended to be greater than measured ice-drift speeds (Tchernia \& Jeannin 1984, Ohshima et al. 1996, Heil \& Allison 1999), indicating that the PTTs remained attached to the penguins over this period, at least. From May onward travel speeds and directions were more typical of expected ice movements and thus we were less confident in assuming that the instruments were still on the birds. However, on the basis of results from our summer tracking studies, during which penguins did retain their instruments, we know that 
proportions of low quality fixes increase when birds travel by swimming compared to walking over the ice (Clarke \& Kerry unpubl. data). We thus expected to find a positive relationship between travel speed and proportion of Class 1 fixes (Table 3), based on the assumption that the faster the penguins travel, the more time they will spend in the water. Pooled monthly data from the 4 fledglings tracked in 1997 indeed showed a significant linear relationship between the proportion of Class 1 fixes and mean speed of travel (see 'Results'). We are thus confident that the PTTs did remain attached to the fledglings throughout the study.

It was required that instruments remained attached to the post-moult adults for several months longer than the fledglings in order to provide data throughout winter and into spring. We wished to ensure as far as possible that the tracks shown in Figs. 4 \& 5 indeed referred to penguins rather than to ice movement alone. After mid-August, Adult 2670 travelled at speeds faster than those expected of ice motion. Data from this bird showed a positive relationship between mean travel speed and proportion of Class 1 fixes received per duty-cycle during late August and September, indicating that it was actively swimming for much of this period.

Another line of investigation we followed was the analysis of diurnal patterns of fixes received from PTTs in relation to numbers of satellite passes available (see 'Results'). Adélie penguins are known to forage predominantly during daylight hours (Wilson et al. 1989); thus we expected to obtain on average fewer fixes per satellite pass during the day than at night for foraging birds. Both Adult 2670 and Adult 2673 showed significantly lower numbers of fixes between 06:00 and 18:00 $\mathrm{h}$ local time than would be expected if the PTTs had been positioned on the ice.

Taken together, the above investigations suggest that most if not all of the PTTs did remain attached to the penguins throughout the period that transmissions were received. We believe that in most cases lost devices either fall into the water or become covered with snow soon after detachment and therefore cease to transmit effectively. A range of dates of loss of instruments may thus explain the variation in overall transmission time between the different PTTs.

\section{Penguin travel in relation to currents and ice movement}

Studies during the breeding season at Mawson and Davis have shown that Adélie penguins in these regions of East Antarctica forage within a $120 \mathrm{~km}$ radius of their colony in order to bring back regular meals for their chicks (Kerry et al. 1995, 1997, Clarke et al. 1998, Irvine et al. 2000). In the only previous study of post-breeding Adélie penguin migration, Kerry et al. (1995) found that after leaving their colonies adult birds travelled westward along the edge of the shelf break, at the level of the flaw lead between the fast-ice and the pack. Until now it remained unknown whether the birds continued moving west, how far they travelled and at what latitudes and rates they returned to their breeding sites. Likewise, nothing was known about where fledgling penguins went when they departed from their natal colonies for the first time.

The tracking data shown in this paper confirm the findings of Kerry et al. (1995) that during the autumn months post-moult adults from Béchervaise Island travel westward at the fast-ice margin. Two of the 3 post-moult adults tracked in the Ross Sea showed a similar tendency to travel along the edge of the continental shelf during late autumn (Davis et al. 1996, 2001). Fledglings from both Magnetic and Béchervaise Islands follow a similar winter migration pattern to the adults, although initially some seem to 'explore' farther north (and even east), before heading westward. The flaw lead between the fast-ice and the pack-ice is visible in satellite images throughout winter (Fig. 3). It appears that both adults and fledglings travel westward at this level, feeding as they go and are able to rest in comparative safety on solid ice when not searching for food.

Five of the 6 fledglings that departed from Mawson travelled northward over deep water to latitudes between 63 and $64^{\circ} 30^{\prime} \mathrm{S}$ before heading back toward the edge of the continental shelf. Their turning points were within the belt of upwelling of Circumpolar Deep Water (CDW) which is found between 63 and $65^{\circ} \mathrm{S}$ north of Mawson (Wakatsuchi \& Ohshima 1994, Orsi et al. 1995). During April, 5 of the 6 fledglings remained over the continental slope at the northern margin of the developing sea-ice (Fig. 2) where waters are between 1000 and $2000 \mathrm{~m}$ deep and where krill densities tend to be greatest in summer (Hosie et al. 1988, Kerry et al. 1997).

Both adult and juvenile birds travelled all the way around Enderby Land and past the Rïser Larsen into the Haakon VII Sea where they slowed down and spent time foraging. Proportions of high quality fixes increased at this stage, indicating that the birds were spending more of their time resting on ice floes and had perhaps found localities where food supplies were plentiful (Table 3). From there, in the second half of winter, the adults turned northward and one returned toward the east at latitudes of 61 to $63^{\circ} \mathrm{S}$. The westward journey of post-moult adults took place at speeds similar to the westward current in that region (Tchernia \& Jeannin 1984, Allison 1989, Ohshima et al. 1996, Heil \& Allison 1999). The eastward return of the pen- 
guin carrying PTT 2670 occurred sufficiently far north for the bird to take advantage of currents flowing in the other direction (Orsi et al. 1995, Emery et al. 1997, Heil \& Allison 1999) while remaining within the packice (Figs. 4 \& 5).

On the basis of their tracking work and other studies, Davis et al. (1996, 2001) postulated that Adélie penguins in the Ross Sea region travel to common overwinter feeding grounds. Although it is possible that the Adélie penguins of East Antarctica similarly travel to common foraging areas, we believe instead that the birds allow themselves to drift westward in the ocean currents, feeding as they go, before eventually moving north with the expanding pack-ice into the eastwardflowing ACC, which then assists them to return toward their colonies. Post-moult Adult 2670 was the only penguin tracked over sufficient time and distance to definitively move from the region of westward flow into the ACC. In so doing it crossed the Antarctic Divergence (AD), defined as a region of high zonal shear dividing the westward flowing coastal current from the eastward flow of the ACC (Heil \& Allison 1999). The AD correlates closely with the southern boundary of the ACC (Orsi et al. 1995), which has been identified as a region of high biological productivity (Tynan 1998). Fig. 6 provides a schematic representation of water mass boundaries and patterns of ice movement in the region through which our penguins travelled. It is possible that the penguins make use of a northward flowing eastern arm of the Weddell Gyre (Emery et al. 1997) to move north in the pack-ice across the AD into the region of eastward flow.

\section{Winter foraging grounds and gyral oceanic systems}

High concentrations of krill Euphausia superba have been associated with the maximal winter extent of sea ice (Marr 1962, Mackintosh 1973, Marschall 1988, Pakhomov \& McQuaid 1996, Tynan 1998, Nicol et al. 2000) and the outer edge of the pack-ice in spring (Daly \& Macaulay 1991, Quetin et al. 1996). These locations correlate closely with the southern boundary of the ACC (Orsi et al. 1995, Tynan 1998) and waters to the south of it (Nicol et al. 2000). Higher predators can be expected to exploit these regions as reliable food supplies, as has been shown to be the case for various whale species in spring and summer (Tynan 1998). It is possible that gyral ocean currents carry Adélie penguins from colonies along the coasts of Enderby, Kemp and Mac.Robertson Lands into productive waters at the eastern margin of the Weddell gyre. Krill have been found under the sea-ice during winter and spring (Nordhausen 1994, Quetin et al. 1996 and references therein), particularly in the Weddell Sea (Marschall

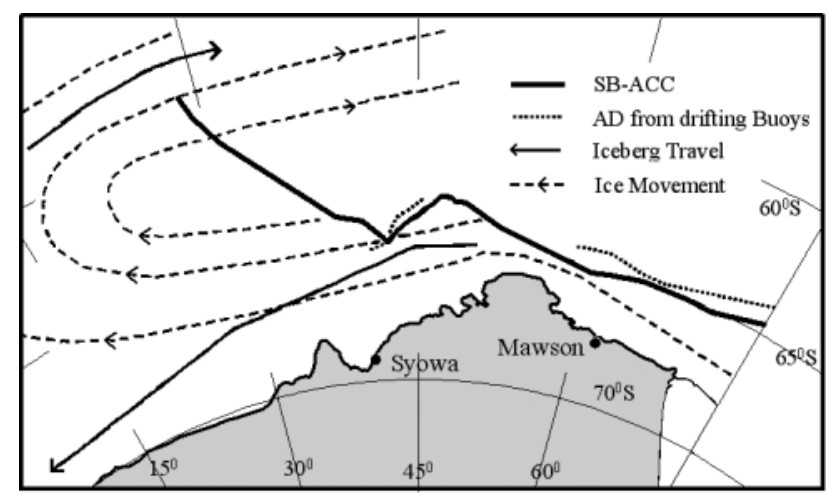

Fig. 6. Schematic diagram showing water mass boundaries and ice movement patterns north of the Antarctic coastline between 15 and $70^{\circ} \mathrm{E}$. The position of the southern boundary of the Antarctic Circumpolar Current (SB-ACC) is adapted from Orsi et al. (1995) and the location of the Antarctic Divergence (AD) reproduced from Heil \& Allison (1999). Directions of iceberg travel and sea-ice movement are adapted from Tchernia \& Jeannin (1984) and Emery et al. (1997) respectively

1988, Daly \& Macaulay 1991) and off Enderby Land (O'Brien 1987), and often at highest concentrations within $200 \mathrm{~km}$ of the outer edge of the pack-ice (Daly \& Macaulay 1991). Adélie penguins are known to feed on krill, fish and cephalopods during winter (Ainley et al. 1992) in the Scotia-Weddell Confluence region, and are likely to be foraging similarly in the Haakon VII Sea.

Northward migration during August and September will not only allow Adélie penguins access to eastward flowing ocean currents but may also enable them to take advantage of high Euphausia superba concentrations found in the decaying outer pack-ice during spring (Marschall 1988, Daly \& Macaulay 1991). Plentiful food supplies are necessary for the birds prior to arrival at their breeding colonies in late October and early November. We have found that in summer Adélie penguins take predominantly gravid female E. superba (Clarke et al. 2002) which spawn at that time of year. Another euphausiid, Thysanoessa macrura, was found to be the most abundant krill species found within the pack-ice zone north of Enderby Land in late winter (Hosie \& Stolp 1989, Hosie 1991). T. macrura spawns from September onward, (Hosie \& Stolp 1989, Nordhausen 1994) so it is possible that as the penguins return toward their breeding colonies in spring, they also feed on gravid females of that species.

Comparison of the penguin tracks with ice-drift patterns suggests that Adélie penguins may utilise current-driven ice movements during the winter months as they migrate away from their land-based colonies and, more importantly, as a means of transport back towards their breeding sites in spring. Other gyral sys- 
tems exist between 80 and $140^{\circ} \mathrm{E}$ in the Ross Sea, and may be similarly important for penguins breeding in these regions. The movements of the 3 Adélie penguins tracked in early winter in the Ross Sea (Davis et al. 1996, Davis et al. 2001) are consistent with this proposal.

Further tracking studies from other locations and within different gyres are required to confirm our hypothesis that Adélie penguins utilize gyral current systems over the winter months. For example, are birds from other colonies along the eastern Antarctic coastline able to make use of the gyre in a similar way to those from Béchervaise Island? Adélie penguins are well synchronised in the timing of their breeding cycle; thus penguins from Syowa $\left(30^{\circ} \mathrm{E}\right)$ (Fig. 4), which enter and move with the gyre, will commence their winter journeys at the same time but farther to the west than those from Béchervaise Island $\left(64^{\circ} \mathrm{E}\right)$. The decision for these birds therefore is whether to complete the circuit sooner, or to remain longer in a particular area and then towards the end of winter move directly to their colony. Furthermore, if the utilisation of oceanic gyres by migrating penguins is found to be a widespread phenomenon, there will be some important consequences. This form of ecological constraint could lead to genetic isolation of populations, although there might still be sufficient mixing of border groups to ensure a degree of gene flow (Roeder et al. 2001). Nonetheless, the identification of ecological boundaries based on positions of oceanic gyres could provide new insights into the structure and function of Antarctic ecosystems. Such boundaries could become useful for management purposes, for example as an appropriate adjunct to the existing statistical areas used by the Commission for the Conservation of Antarctic Marine Living Resources (CCAMLR) in the regulation of the Antarctic krill fishery (CCAMLR 2002).

Acknowledgements. We thank David Watts of the Australian Antarctic Division for assistance with mapping of satellite data, Andrew Townsend for development of the penguin database and Louise Emmerson for statistical advice. We are grateful for the valuable efforts of Trevor Taylor, Joanne Gallagher, Mike Anderson and Lyn Irvine in the field, and thank the members of the Australian National Antarctic Research Expeditions (ANARE) for logistical support. We are also grateful to Grant Else, Brad Phillips, David Clement and Peter Kernebone for technical assistance.

\section{LITERATURE CITED}

Ainley DG, Ribic CA, Fraser WR (1992) Does prey preference affect habitat choice in Antarctic seabirds? Mar Ecol Prog Ser 90:207-221

Ainley DG, Ribic CA, Spear LB (1993) Species-habitat relationships among Antarctic seabirds: a function of physical or biological factors? Condor 95:806-816
Ainley DG, Ribic CA, Fraser WR (1994) Ecological structure among migrant and resident seabirds of the ScotiaWeddell Confluence region. J Anim Ecol 63:347-364

Ainley DG, Jacobs SS, Ribic CA, Gaffney I (1998) Seabird distribution and oceanic features of the Amundsen and southern Bellingshausen seas. Antarct Sci 10:111-123

Allison I (1989) Pack-ice drift off East Antarctica and some implications. Ann Glaciol 12:1-8

Cavalieri DJ, Gloersen P, Parkinson CL, Comiso JC, Zwally HJ (1997) Observed hemispheric asymmetry in global sea ice changes. Science 278:1104-1106

CCAMLR (2002) Conservation measure 106/XIX: precautionary catch limitation on Euphausia superba in statistical division 58.4.1. Schedule of conservation measures in force 2001/2002. CCAMLR, Hobart

Clarke JR (2001) Partitioning of foraging effort in Adélie penguins provisioning chicks at Béchervaise Island, Antarctica. Polar Biol 24:16-20

Clarke JR, Kerry KR (1998) Implanted transponders in penguins: implantation, reliability, and long term effects. J Field Ornithol 69:149-159

Clarke JR, Manly B, Kerry KR, Gardner H, Franchi E, Corsolini S, Focardi S (1998) Sex differences in Adélie penguin foraging strategies. Polar Biol 20:248-258

Clarke J, Kerry K, Irvine L, Phillips B (2002) Chick provisioning and breeding success of Adélie penguins at Béchervaise Island over eight successive seasons. Polar Biol 25:21-30

Comiso JC (1995) SSM/I concentrations using the Bootstrap Algorithm. NASA Contract Rep 1380:40

Daly KL, Macaulay ML (1991) Influence of physical and biological mesoscale dynamics on the seasonal distribution and behavior of Euphausia superba in the antarctic marginal ice zone. Mar Ecol Prog Ser 79:37-66

Davis LS, Boersma PD, Court GS (1996) Satellite telemetry of the winter migration of Adélie penguins Pygoscelis adeliae. Polar Biol 16:221-225

Davis LS, Harcourt RG, Bradshaw CJA (2001) The winter migration of Adélie penguins breeding in the Ross Sea sector of Antarctica. Polar Biol 24:593-597

Emery WJ, Fowler CW, Maslanik JA (1997) Satellite-derived maps of Arctic and Antarctic sea ice motion. Geophys Res Lett 24:897-900

Fraser WR, Trivelpiece WZ (1996) Factors controlling the distribution of seabirds: winter-summer heterogeneity in the distribution of Adélie penguin populations. Antarct Res Ser 70:257-272

Heil P, Allison I (1999) The pattern and variability of Antarctic sea-ice drift in the Indian Ocean and western Pacific sectors. J Geophys Res 104:15789-15802

Hosie GW (1991) Distribution and abundance of euphausiid larvae in Prydz Bay regions, Antarctica. Antarct Sci 3: $167-180$

Hosie GW, Stolp M (1989) Krill and zooplankton in the Western Prydz Bay region, September-November 1985. Proc NIPR Symp Polar Biol 2:33-45

Hosie GW, Ikeda T, Stolp M (1988) Distribution, abundance and population structure of the Antarctic krill Euphausia superba Dana in the Prydz Bay region, Antarctica. Polar Biol 8:213-224

Irvine L, Clarke JR, Kerry KR (2000) Poor breeding success of the Adélie penguin at Bechérvaise Island in the 1998/99 season. CCAMLR Sci 7:151-167

Kerry KR, Clarke JR, Else GD (1995) The foraging range of Adélie Penguins at Béchervaise Island, Mac.Robertson Land, Antarctica as determined by satellite telemetry. In: Dann P, Norman FI, Reilly PN (eds) The penguins: ecology and management. Surrey-Beatty, Sydney, p 216-243 
Kerry KR, Clarke JR, Eberhard SE, Gardner H, Lawless RM, Tremont R, Wienecke B (1997) The foraging range of Adélie penguins - implications for CEMP and interactions with the krill fishery. CCAMLR Sci 4:75-87

Mackintosh NA (1973) Distribution of post-larval krill in the Antarctic. Disc Rep 36:95-156

Marr JWS (1962) The natural history and geography of the Antarctic krill (Euphausia superba Dana). Disc Rep 33: 33-464

Marschall H (1988) The overwintering strategy of Antarctic krill under the pack-ice of the Weddell Sea. Polar Biol 9: 129-135

Nicol S, Pauly T, Bindoff NL, Wright S, Thiele D, Hosie GW, Strutton PG, Woehler E (2000) Ocean circulation off east Antarctica affects ecosystem structure and sea-ice extent. Nature 406:504-507

Nordhausen W (1994) Winter abundance and distribution of Euphausia superba, E. crystallorophias, and Thyanoessa macrura in Gerlache Strait and Crystal Sound, Antarctica. Mar Ecol Prog Ser 109:131-142

O'Brien DP (1987) Direct observations of the behavior of Euphausia superba and Euphausia crystallorophias (Crustacea: Euphausiacea) under pack-ice during the Antarctic spring of 1985. J Crustac Biol 7:437-448

Ohshima KI, Takizawa T, Ushio S, Kawamura T (1996) Seasonal variations of the Antarctic coastal ocean in the vicinity of Lützow-Holm Bay. J Geophys Res 101: 20617-20628

Orsi AH, Whitworth T III, Nowlin WD (1995) On the meridional extent and fronts of the Antarctic Circumpolar Current. Deep-Sea Res 42:641-673

Pakhomov EA, McQuaid CD (1996) Distribution of surface zooplankton and seabirds across the Southern Ocean. Polar Biol 16:271-286

Pütz K, Ingham RJ, Smith JG (2000) Satellite tracking of the winter migration of Magellanic penguins Spheniscus magellanicus breeding in the Falkland Islands. Ibis 142: 614-622

Quetin LB, Ross RM, Frazer TK, Haberman KL (1996) Factors affecting distribution and abundance of zooplankton, with

Editorial responsibility: Otto Kinne (Editor),

Oldendorf/Luhe, Germany an emphasis on Antarctic krill, Euphausia superba. Antarct Res Ser 70:357-371

Roeder AD, Marshall RK, Mitchelson AJ, Visagathilagar R and 8 others (2001) Gene flow on the ice: genetic differentiation among Adélie penguin colonies around Antarctica. Mol Ecol 10:1645-1656

Service Argos (1996) User Manual. Service Argos, Washington, DC

Stokes DL, Boersma PD, Davis LS (1998) Satellite tracking of Magellanic penguin migration. Condor 100:376-381

Tchernia P, Jeannin PF (1984) Circulation in Antarctic waters as revealed by iceberg tracks 1972-1983. Polar Rec 22: 263-269

Tynan CT (1998) Ecological importance of the southern boundary of the Antarctic circumpolar current. Nature 392:708-710

Wakatsuchi M, Ohshima KI (1994) Observations of a street of cyclonic eddies in the Indian Ocean sector of the Antarctic Divergence. J Geophys Res 99:20417-20426

Watanuki Y, Kato A, Naito Y, Robertson G, Robinson S (1997) Diving and foraging behaviour of Adélie penguins in areas with and without fast sea-ice. Polar Biol 17:296-304

Whitehead MD (1989) Maximum diving depths of the Adélie penguin, Pygoscelis adeliae, during the chick rearing period, in Prydz Bay, Antarctica. Polar Biol 9:329-332

Whitehead MD, Johnstone GW, Burton HR (1990) Annual fluctuations in productivity and breeding success of Adélie penguins and fulmarine petrels in Prydz Bay, East Antarctica. In: Kerry KR, Hempel G (eds) Antarctic ecosystems, ecological change and conservation. SpringerVerlag, Berlin, p 214-223

Wilson RP, Culik BM, Coria NR, Adelung D, Spairani HJ (1989) Foraging rhythms in Adélie penguins Pygoscelis adeliae at Hope Bay, Antarctica; determination and control. Polar Biol 10:161-165

Wilson RP, Culik BM, Kosiorek P, Adelung D (1998) The overwinter movements of a chinstrap penguin (Pygoscelis antarctica). Polar Rec 34:107-112

Woehler EJ (1993) The distribution and abundance of Antarctic and Subantarctic penguins. SCAR, Cambridge

Submitted: May 24, 2002; Accepted: September 20, 2002

Proofs received from author(s): February 11, 2003 